
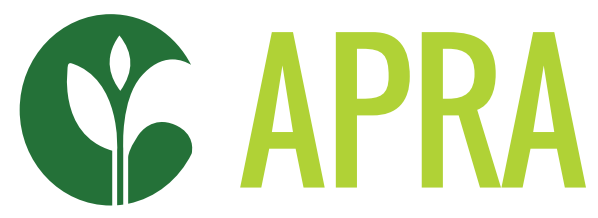

Agricultural Policy Research in Africa

\title{
INTERROGATING THE EFFECTIVENESS OF FARMER PRODUCER ORGANISATIONS IN ENHANCING SMALLHOLDER COMMERCIALISATION - FRONTLINE EXPERIENCES FROM CENTRAL MALAWI
}

Masautso Chimombo, Mirriam Matita, Loveness Mgalamadzi, Blessings Chinsinga, Ephraim Wadonda Chirwa, Stevier Kaiyatsa and Jacob Mazalale 


\section{TABLE OF CONTENTS}

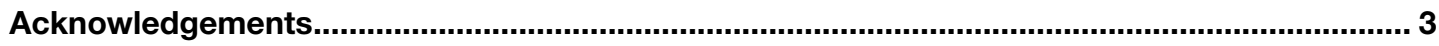

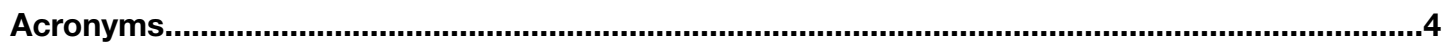

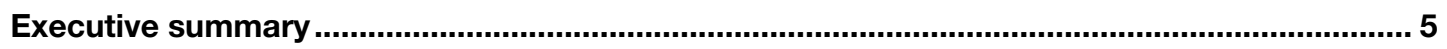

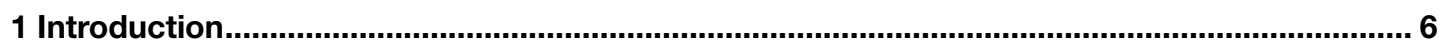

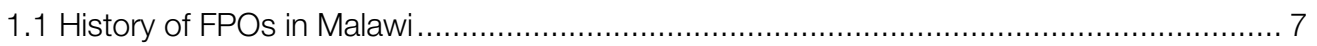

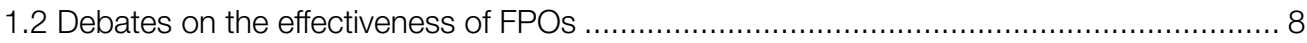

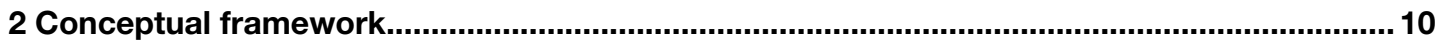

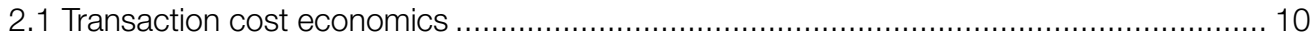

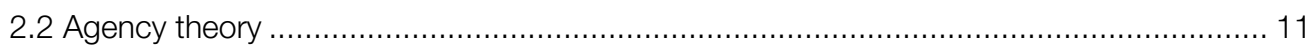

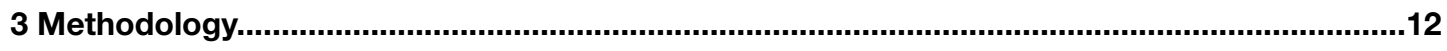

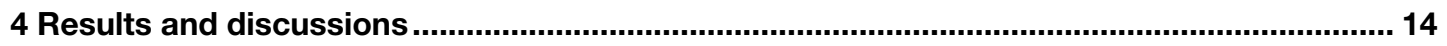

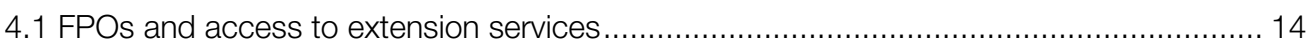

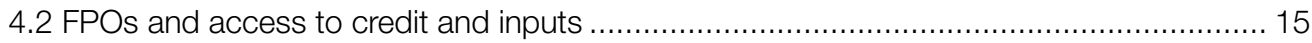

4.3 FPOs and access to structured and profitable markets.............................................. 17

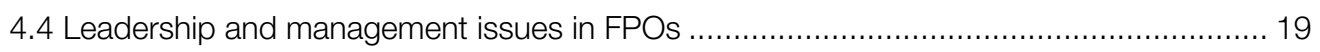

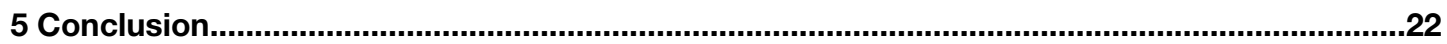

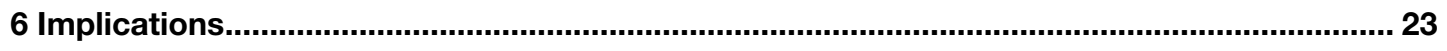

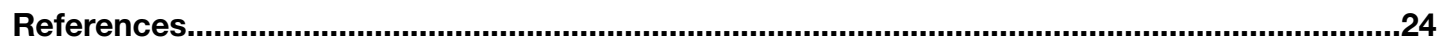




\section{ACKNOWLEDGEMENTS}

We would like to extend our deepest appreciation to smallholder farmers and frontline extension workers in Mchinii and Ntchisi districts for their cooperation during the several rounds of data collection. By answering our research questions, they made this working paper possible. Our gratitude also goes to the Information, Communication and Engagement team at Institute of Development Studies (IDS) for their great input in copy editing and formatting the working paper. We thank both internal and external reviewers for their insightful guidance which greatly shaped the direction of this working paper.

Masautso Chimombo is a lecturer of Rural Sociology in the Extension Department at the Lilongwe University of Agriculture and Natural Resources (LUANAR). Mirriam Matita is a lecturer in Research Methods in the Extension Department at LUANAR and a PhD student in Economics at the University of Malawi. Loveness Msofi Mgalamadzi is a lecturer in Extension and Rural Development in the Extension Department at LUANAR and a PhD student at the Institute for Poverty, Land and Agrarian Studies (PLAAS) at the University of the Western Cape, in South

Africa. Blessings Chinsinga is a Professor of Political Economy at the Department of Political and Administrative Studies, University of Malawi. The late Ephraim Wadonda Chirwa was Emeritus Professor of Economics at the University of Malawi. Stevier Kaiyatsa is an economist for the Government of Malawi. Jacob Mazalale is a lecturer at the University of Malawi in the Department of Economics.

This working paper is funded with UK aid from the UK government (Foreign, Commonwealth \& Development Office - FCDO, formerly DFID). The opinions are the authors and do not necessarily reflect the views or policies of IDS or the UK government. 


\section{ACRONYMS}

ACE

Agricultural Commodity Exchange

ADMARC Agricultural Development and Marketing Corporation

APRA Agricultural Policy Research in Africa

CFTC Competitions and Fair Trading Commission

EPA extension planning area

FGD focus group discussion

FPO farmer producer organisation

KII key informant interview

LHI life history interview

NASFAM National Association of Smallholder Farmers of Malawi

NGO non-governmental organisation

WRS warehouse receipt system 


\section{EXECUTIVE SUMMARYY}

Many years of significant investment into the production and adoption of productivity-enhancing technologies and practices in agriculture have not yielded the desired results. Most smallholder farmers in Africa remain trapped in poverty. Having realised that addressing production challenges alone is not enough to impact the lives of poor smallholder farmers, resources and attention have now shifted to the marketing side of agriculture. Organising farmers into farmer producer organisations (FPOs), like clubs, associations and cooperatives, has been one of the strategies aimed at commercialising smallholder agriculture. In Malawi, smallholder farmers have been organised into FPOs of various types and sizes. This qualitative study interrogated the effectiveness of FPOs in Malawi in meeting their objectives, including the objective of enhancing commercialisation of smallholder farmers through increased access to farm inputs, markets, and agricultural extension and advisory services. Mchini and Ntchisi districts in central Malawi were sampled for the study. We found that while farmers who are members of FPOs have more and frequent access to extension services and affordable inputs, member farmers do not enjoy any advantage over their non-member counterparts when it comes to access to markets and incomes. On the contrary, we found that in some cases farmer members of FPOS face more disadvantages on the market, as they sell their produce too late in the selling season when even exploitative vendors are unwilling to buy. This results in member farmers accepting even lower prices for their produce; situations which leave them with very low farm incomes. There is a need, therefore, to dedicate more resources and a lot of brainstorming in coming up with new models of FPOs that have the capacity to secure profitable markets for farmers, and that will enable the generation of higher farm incomes for their members. 


\section{INTRODUCTION}

Agriculture, the biggest employer in most African countries, has failed to move smallholder farmers out of poverty (Tittonell and Giller, 2013; Collier and Dercon, 2014). To move the poor and mostly rural smallholder farmers out of poverty, past strategic efforts focused on modernising farming husbandry practices through the provision of extension and advisory services that promoted the adoption of modern agricultural innovations and technologies by smallholder farmers (Fischer and Qaim, 2012; Mango et al., 2017). Thus, extension workers were responsible for building the modern and science-informed productive capacities of smallholders. However, despite a lot of effort and resources being spent on building smallholder farmers' capacity to practice modern farming, poverty levels among smallholder farmers in Africa have either remained static or, in most cases, worsened. Accordingly, scholars and policymakers have realised that focusing on the production side alone has failed to improve the livelihoods of smallholder farmers and therefore interventions aimed at enhancing smallholder access to markets have begun to gain a lot of attention and resources (von Braun, Kennedy and Bouis, 1990; Bernard, Seyoum, and Gabre-Madhin, 2008; GabreMadhin, 2009; Arias et al., 2013; Mango et al., 2017)

The integration of smallholder farmers into the market - often defined by the proportion of farm output that is sold on the market, versus the amount consumed by the household (Fafchamps, 1992; Timmer, 1997); sometimes called 'commercialisation' (Pingali and Rosegrant, 1995; von Braun, 1995), 'market participation' (Bellemare and Barrett, 2006; Barrett, 2008), or 'market orientation' (Gebremedhin and Jaleta, 2010) - is seen as a magic bullet that can effectively rescue smallholder farmers out of the poverty trap. There is consensus that if the livelihoods of smallholder farmers and rural livelihoods are to meaningfully transform, farmers need to target and transact more with markets through smallholder agricultural commercialisation (von Braun, Kennedy and Bouis, 1990; Pingali, 1997; Dollar and Kraay, 2004; Keller and Shiue, 2007).

However, previous studies have shown that smallholder farmers face a lot of challenges that disadvantage them in agricultural markets. With poor infrastructure, small farms, and few assets, which prevent them from realising economies of scale, smallholder farmers face higher transactional costs that reduce their incentive for market participation (Fischer and Qaim, 2012; Ampaire, Machethe and Birachi, 2013). In addition, smallholder farmers' limited access to agricultural extension, advisory services, and credit results in them harvesting produce quantities that are too low for profitable market engagement (Fischer and Qaim, 2012; Tolno et al., 2015). Predatory opportunistic behaviour of some big actors on the market that prey on and take advantage of smallholder farmers is another barrier that is frustrating efforts towards commercialising smallholder agriculture (Fischer and Qaim, 2012).

Aware of the challenges that smallholder farmers are facing in their quest to improve their livelihoods, there is renewed interest from donors, governments, and researchers in FPOs as vehicles for enhancing smallholderfarmers performance in market participation (IMF 2007; Benard and Spielman, 2009 as cited in Tolno et al., 2015; Eliasi, Aubin and Sunga, 2009; Arias et al., 2013; Mango et al., 2017). FPOs have been touted to be one of the effective means for overcoming the challenges faced by smallholder farmers by promoting collective marketing (Birchall, 2004 as cited by FAO, 2007; Shiferaw, Hellin and Muricho, 2011; Ampaire, Machethe and Birachi 2013). According to Rondot and Collion (2001), FPOs are formal rural organisations whose members are smallholder farmers who organise themselves with the objective of improving farm income through improved production, marketing, and local processing activities. FPOs include cooperatives, farmers associations, farmer clubs, farmer savings and credit societies, and rural producer organisations among others. Activities of FPOs include organising farmers to receive external support, bulk purchase and distribution of inputs, aggregation and joint sale (or buying) of farmer products, handling and storage, processing, transportation, mechanisation services for farmers, and creation of access to finance from banks and microfinance institutes (SNV, 2016). To what extent FPOs in Malawi are able to perform such activities is an important question of investigation, given the fact that smallholder farmers in the country are still synonymous with poverty. This paper therefore assesses the 
effectiveness of FPOs in enhancing smallholder farmer commercialisation. It does this by interrogating the roles that FPOs in Malawi are playing in facilitating smallholder farmers' access to agricultural production and agricultural marketing services. Challenges which FPOs face have also been presented in this paper.

The main finding is that while FPOs in Malawi have succeeded in increasing their members' access to extension services and farm inputs through input loans and savings, they have failed in addressing the output marketing challenges which have for a long time negatively trapped smallholder farmers in chronic poverty. The paper therefore recommends a rethink on FPOs, paying attention to how FPOs in Malawi can succeed in meeting their marketing objectives and realising increased income earnings for their members. Without this, there is a greater risk of farmers withdrawing their membership from FPOs or being apathetic FPO members.

The rest of section 1 proceeds by presenting a brief history of FPOs in Malawi which is followed by a discussion of the debates around the effectiveness of FPOs in achieving their farmer-centred objectives. A conceptual framework covering transaction cost economics and agency theory is presented in section 2 of the paper. Section 3 and section 4 present the methodology and results respectively, while the conclusion and implications are presented in section 5 and section 6 respectively.

\subsection{History of FPOs in Malawi}

In Malawi, the first FPOs to be formed were cooperatives created in 1946 by the colonial government with an aim of integrating the local population into the cash economy (Kachule, 2004; Kadzola, 2009). These early cooperatives were established under the Cooperatives Act of 1946 (ibid) and received a lot of support from the colonial government as cooperatives were being established to make it easier for the colonial government to collect tax from local smallholder farmers. The failure rates among these early cooperatives were very high due to, among other reasons, high levels of illiteracy and failure to understand roles and obligations of cooperatives by the member farmers (Lynx Associates, 1996 as cited in Kachule, 2004). At the dawn of selfrule in 1964, the then prime minister of Nyasaland, Dr Hastings Kamuzu Banda, abolished the cooperatives, accusing them of serving the interests of state-owned enterprises who were still under the influence of the deposed colonial rulers (Kadzola, 2009). The Kamuzu regime instead established the state-owned Agricultural Development and Marketing Corporation (ADMARC), which became the sole buyer of farm produce and supplier of farm inputs. However, in 1978 other forms of
FPO started to emerge, such as farmer clubs that were used as channels through which agricultural credit and agricultural extension services were delivered to smallholder farmers (Kishindo, 1988 as cited in Mapila, Makwenda and Chitete, 2010). Since then FPOs in Malawi have taken many forms and presently include the National Association of Smallholder Farmers of Malawi (NASFAM), Farmers Union of Malawi, Kasinthula Cane Growers Association, Tobacco Association of Malawi, Mzunzu Coffee Growers Association, commodityspecific associations and cooperatives among many others (ibid).

The FPOs that began in 1978 and existed up to 1994, at the dawn of multiparty democracy, were the most effective and successful FPOs in Malawi's history (Kachule, 2004). Through the farmer clubs, smallholder farmers were able to access adequate extension services, farm input loans, and sold their produce at higher prices to the sole state-owned produce buyer, ADMARC. The role of the private sector during this epoch was very limited as the government had a tight grip on businesses and the economy. Minimum prices and official dates for commencement of produce buying which were set by the government were all strictly adhered to because any disobedience to policies and pronouncements made by the government during the one-party era had severe and grave consequences. It can therefore be argued that during this period, fear, the resultant discipline among smallholder farmers, and the sole state producer buyer ADMARC's adhering to set minimum pricing, contributed to the success and effectiveness of farmer clubs. The coming in of democracy demystified the ruling party and the state presidency, arguably leading to low levels of obedience to government policies, including those governing the operations of FPOs.

Since 1978, the Government of Malawi has continued to show sustained commitment to ensuring that Malawi has thriving and effective FPOs. Governments have shown this commitment in several ways. For a start, several governments have developed and put in place legislative pieces that allows for the establishment and operationalisation of different FPOs at different levels, including at national level, district level and at grassroots level (Mapila, Makwenda and Chitete, 2010). Apart from specific acts of parliament that encourage the formation of tertiary level FPOs, such as the Cooperative Societies Act (1998) and Cooperative Society Regulations (2002), many policy documents from different sectors recognise that the development of FPOs is a key strategy for growth in agricultural and rural development (ibid). This aim continues, with the first 10-year implementation plan for Malawi's 2063 development agenda clearly prescribing the need 
for establishing and strengthening FPOs in order to enhance the linkage of smallholder farmers to markets (Government of Malawi, 2021).

FPOs in Malawi are still governed by the Cooperative Societies Act of 1998, and their development is guided by the 1997 Cooperatives Development Policy. According to the Act, at government level, the registration, oversight, and other regulatory functions of FPOs fall under the Department of Cooperatives in the Ministry of Industry and Trade. The Department of Cooperatives is headed by a registrar of cooperatives and in 2014 the whole office had eight officers at the national headquarters (Vicari and Borda-Rodriguez, 2014; ILO, 2017). Despite having an officer at each district headquarters, only these eight officers are mandated to provide training to leaders of cooperatives as a pre-condition for their registration. The officers have to serve the whole of Malawi and fail to meet the demand for their services in a timely manner. Despite offering financial and technical support to cooperatives, both the 1998 Cooperative Societies Act and the 1997 Cooperatives Development Policy clearly stipulate that cooperatives are independent profit-making entities owned by their members and are required to adhere to the following cooperative principles as enshrined in the regulatory and policy documents of the International Cooperative Alliance:

i. Open and voluntary membership

ii. Democratic member control

iii. Members' economic participation

iv. Autonomy and independence

v. Education, training, and information

vi. Cooperation among cooperatives

vii. Concern for community

Most smallholder tobacco farmers have been organised into some kind of FPO since tobacco production was introduced in Malawi (Kumwenda and Madola, 2005). Tobacco clubs, associations, and cooperatives have been the norm over the decades. However, the government noted that most smallholder tobacco farmers were under the perpetual trap of low tobacco yields due to their low input use and low access to agricultural extension and advisory services (Government of Malawi, 2016). Contract farming was therefore added to the activities of tobacco FPOs with an aim of increasing smallholder tobacco farmers' access to tobacco yield-enhancing inputs and increasing farmers access to agricultural extension and advisory services with the ultimate aim of increasing tobacco yields and incomes (ibid).
Contract farming is an agricultural production and marketing enterprise performed under a formal agreement between a buyer and a farmer or group of farmers in which the buyer is obliged to purchase specified agricultural product(s) at a predetermined price or price formula, quantity and quality, and the producer(s) is obliged to sell the specified agricultural product(s) to the contract buyer (Government of Malawi, 2016). Under tobacco farming in Malawi, the contract states that the tobacco companies provide agricultural loans to farmers to cover the costs of chemical fertilisers, watering cans, recommended hybrid tobacco seeds, and pesticides among other things. The tobacco companies also employ their own agronomists and extension workers who provide tobacco extension and advisory services to the contracted farmers and also monitor the use of child labour at all levels in the tobacco production value chain (Kumwenda and Madoda, 2005; Government of Malawi, 2016; Shaba et al., 2017). In turn, the tobacco farmers have the responsibility to follow good agricultural practices, like applying the right amount of fertiliser at the right frequency, and ensure that they do not use children as labourers (ibid). In addition, the contracted tobacco farmers are under obligation to sell all of their contract tobacco to the tobacco company under which they are contracted. According to the Malawi Contract Farming Strategy, which was launched in 2016, to protect farmers' interests, smallholder farmers are encouraged to have their contracts vetted by the Competitions and Fair Trading Commission (CFTC) before entering into contract with companies (Government of Malawi, 2016).

\subsection{Debates on the effectiveness of FPOs}

Malawi, through the Ministry of Agriculture's agribusiness section, and other non-governmental organisations (NGOs), has been organising smallholder farmers into clubs, associations and cooperatives for collective marketing purposes. Despite collective marketing drives, most smallholder farmers are still living in abject poverty (Government of Malawi, 2021). The high poverty levels among smallholder farmers in Malawi has ignited a debate as to whether indeed collective marketing using the platform of FPOs results in successful and profitable commercialisation of smallholder agriculture in Malawi.

Some studies have found there to be many benefits. An impact evaluation report conducted by DeVoe (2014) for the Wellness and Agriculture for Life Advancement project in Malawi found that farmers who were members of FPOs did not only see their farm productivity increase, but the profitability of their farm enterprises doubled. Unlike non-members, members 
of FPOs had access to big companies where they were able to sell their farm produce at higher prices over and above the prices that were prevailing in the country.

A study conducted in Malawi's Balaka District by Mango et al. (2017) corroborates DeVoe's (2014) findings. Indeed, the Balaka study found that FPO membership was associated with a significant improvement in farm income. Precisely, the nearest neighbour matching results showed that farmers who were members of an FPO in the chosen year/harvest season, earned US\$144.15 more than non-members per growing season. A study conducted by Ampaire, Machethe and Birachi (2013) also demonstrated that members of FPOs in Uganda were likely to earn higher annual farm incomes and sell their farm produce at higher prices than non-members.

Other studies however have found poor results on the effectiveness of FPOs in Malawi. FPOs in Malawi have been found to be undermined by numerous challenges. These include poor accountability, poor leadership as well as poor governance issues within FPOs (Mapila, Makwenda and Chitete, 2010). These challenges create an environment of suspicion, mistrust, and animosity among members of FPOs which contribute to farmer organisations' failure to deliver benefits to their members (ibid). According to Tolno et al. (2015), farmers are attracted to FPOs by the potential economic benefits to be derived from being a member, and so any failure to get these economic benefits threatens their willingness to participate.

Mapila, Makwenda and Chitete (2010) found elite capture in FPOs to be one of the barriers preventing the ordinary poor smallholder farmers from benefiting from the existence of FPOs in their localities. Kusumawati and Visser (2016) define elites as actors who have disproportionate influence in the development process as a result of their superior social, cultural, political or economic status. By 'elite capture', sociologists and political economy writers refer to situations where elites shape development processes according to their own priorities and ensure that larger percentages of benefits, resources, and opportunities that arise from community development are enjoyed by them and their immediate family members (ibid). These socialeconomic elites, who include wealthy households as per specific community's standards, traditional leaders and leaders of FPOs, dominate leadership positions, decision-making and even receive most services like attendance of training workshops and access to agricultural loans. Local elites also pursue goals and objectives that are not necessarily in the best interests of ordinary smallholder farmers.

With the literature showing mixed fortunes for different FPOs, and contradictory findings on the effectiveness of FPOs in Malawi, there was indeed a need for this study to contribute to the debate. 


\section{CONGEPTUAL FRAMEWORK}

\subsection{Transaction cost economics}

FPOs like cooperatives have been an important subject of new institutional economics scholarship. New institutional economists have explained agricultural cooperatives, just like any other institution, in terms of their ability to economise on transaction costs (Menard, 2004 as cited in lliopoulos and Valentinov, 2012; Williamson, 2004). Williamson (1985) defined transaction costs as any costs arising out of the process of organising and transacting exchanges. Transaction costs include search and information costs, bargaining and decision costs, and policing and enforcement costs. Economising on transaction costs, in turn, means reducing the scope of the opportunistic behaviour of relevant actors (Williamson, 1996). FPOs perform this function by counteracting the opportunistic behaviour of farmers' contractual partners in the upstream and downstream segments of agricultural value chains (Bonus, 1986; Staatz, 1987).

Both external and internal opportunism are central to the theory of transaction cost economics. Arising out of rent-seeking behaviour and the desire of different individual actors to maximise benefits that accrue to them from business transactions, the opportunism challenge emerges as an unavoidable curse in business transactions, including those involving FPOs. Williamson (1975: 255) famously defined 'opportunism' as 'self-interest seeking with guile'. He argued that 'Economic man is a much more subtle and devious creature than the usual self-interest seeking assumption reveals' (ibid.). Williamson (1985: 47) later elaborated the concept of opportunism in terms of 'the incomplete or distorted disclosure of information, especially to calculated efforts to mislead, distort, disguise, obfuscate, or otherwise confuse'.

Opportunism can be internal or external. External opportunism arises out of rent-seeking behaviour and exploitative tendencies by actors outside of FPOs. Farm input suppliers, government agencies, and produce buyers are potential culprits and beneficiaries of external opportunism at the expense of FPO members. External opportunism often results in cooperatives incurring huge transaction costs in both production and marketing while earning lower revenue from produce sales.
New institution economics also asserts that within a cooperative itself, some members engage in predatory behaviour, aimed at exploiting fellow members of the cooperative. This internal opportunism is thus perpetrated often by powerful members (e.g., cooperative managers and leaders) of the cooperatives on ordinary cooperative members, though sometimes even ordinary members have also been culprits of dishonesty on quality of produce which they submit to cooperatives for aggregation (Williamson, 2014 as cited in Iliopoulos and Valentinov, 2012). As an example of internal opportunism, it is not uncommon in Malawi for ordinary members of tobacco clubs to include nontobacco related materials like rocks and soil in their tobacco bails with an intention of defrauding their clubs and tobacco buyers through dishonestly enhancing tobacco weight (Chirwa, 2011). Internal opportunism is also blamed for causing incentive problems that were threatening the survival of agricultural cooperatives in Greece (Fama, 1980; Fama and Jensen, 1983; Vitaliano, 1983; Cook, 1995; Borgen, 2004; Williamson, 2004). Internal opportunism adversely affects the competitive survival of FPOs. Due to these problems, FPO members are discouraged from investing significant risk capital (Cook and lliopoulos, 2000) and are unable to make efficient collective decisions (lliopoulos and Hendrikse, 2009). Disincentivised, and lacking trust due to internal opportunism in their FPOs, members may deposit a very small proportion of their produce to the produce aggregation centres and engage in side-selling with the remaining proportion of their produce.

As a way of dealing with opportunistic behaviour which is inimical to the development and growth of smallholder agriculture, transaction cost economics proposes the use of contracts to protect vulnerable and weaker actors in farm business transactions from exploitation. Due to the possibility of opportunistic behaviour by one or more parties in a transaction (i.e., to seek private gain at the expense of the group), transaction cost economics views contracts as having a crucial role to play because they enable the parties to fulfil their obligations and protect them from opportunistic behaviour, thus decreasing the costs of transacting (Ortmann and King, 2007). 
In this study, transaction cost economics has provided a framework for analysis and discussion of opportunism, exploitation, and rent-seeking behaviours prevalent in FPOs, especially in their marketing functions. This illuminated and informed the understanding and illumination of frustrations and failures besieging FPOs.

\subsection{Agency theory}

There exists an agency relationship whenever an individual or organisation (the agent) acts on behalf of another (the principal) (Ortman and King, 2007). Since the interests, aspirations, and objectives of the agent and principal are often contradictory and antagonistic, principal-agent problems arise, with an implication that the agent may not always best represent the interests of the principal (Alchian and Demsetz, 1972; Royer, 1999; Sykuta and Chaddad, 1999).

The terms of an agency relationship are specified in and enforced by contractual agreements between agent and principal, specifying roles and obligations for each part to the contract (Royer 1999: 50). Unfortunately, most contracts are incomplete and have loopholes, rendering them ineffective (ibid). Sykuta and Chaddad (1999: 72) pointed out that 'most applications of agency theory focus on the incentive versus risk-sharing trade-off of contracts aimed at aligning the interests of the agent with those of the principal.' Agency theory is thus very relevant to the institutional structure of FPOs because agents (managers/leaders) may not always act in the best interests of FPO owners - the member farmers (principal). Existence of principalagent problems in an FPO may lead to high levels of member dissatisfaction, leading to high member turnover in cooperatives. Agency theory has been used in this study to understand in whose interests' leaders and managers of FPOs in Mchinji and Ntchisi are working for. 
The paper is based on field work conducted in 2018 and 2019 in central Malawi by the Agricultural Policy Research in Africa (APRA) consortium. Specifically, primary qualitative data was collected from Malawi's two central region districts of Mchinji and Ntchisi. APRA Malawi conducted a tracker study which aimed at assessing pathways to agricultural commercialisation of households which were initially studied during the 2006/2007 season by SOAS University of London. Since baseline data was only available for Ntchisi and Mchinji districts, these were therefore purposively sampled for the study. In addition, Ntchisi and Mchinji districts were also purposively chosen because they are among the leading agricultural districts in Malawi in terms of productivity, production and land availability. However, these two districts differ in that Mchinji borders Mozambique and Zambia, while Ntchisi is not a border district, providing a good comparative perspective for the broader APRA study on whether physical closeness to international borders is a catalyst for smallholder agricultural commercialisation. Furthermore, the broader APRA study was interested in understanding the spillover effects of fair trade arrangements by comparing Mchinji (which had a fair trade arrangement championed by NASFAM) and Ntchisi which had no arrangement.

According to Cleland (2017), qualitative research is effective in answering the 'how' and 'why' research questions and enables deeper understanding of experiences, phenomena and context. In this case, the study aimed at understanding farmers experiences as members of FPOs in terms of benefits and challenges and how and why these benefits and challenges come about in their operations. Thus, the study collected qualitative data through key informant interviews (KIIs), focus group discussions (FGDs), and life history interviews (LHIs). The triangulation of FGDs, KIls and LHIs was done to enhance the reliability of the study findings (Yin, 2003).

FGDs were conducted with farmers, separately both for members and non-members of FPOs, focussing on what has been their lived experiences with regards to access to extension services, inputs markets, and output markets. In this study, the FPOs were grassrootlevel based farmer clubs and farmer associations. A farmer association is made of several farmer clubs. In both farmer clubs and farmer associations, the double objective of increasing productivity and profitability for farmer members were the motivations behind their establishment, and members joining. A total 16 and 12 FGDs were conducted in Mchinji and Ntchisi districts respectively. These number of FGDs were adequate as the theoretical saturation point was reached as the last sets of FGDs were not generating any new themes (Guest, Bunce and Johnson, 2006; Silverman 2016; Guest, Namey and Chen, 2020). As argued by Frey and Fontana (1991), FGDs are effective in providing data on realities of a situation as defined in a group context and can therefore be preferable to individual interviews. FGDs can therefore be very effective in understanding the realities of smallholder farmers who are either members or non-members of FPOs. To create a conducive environment for open and active participation by all, each FGD had a minimum of eight participants and a maximum of 12 participants, and leaders of FPOs were separated from ordinary members. Further to that, separate FGDs were conducted for men and women.

Six key informants drawn from each of the two districts were interviewed. Thus, in total the study interviewed 12 key informants, comprising district trade officers, district agri-business officers, district agriculture heads, agricultural extension development officers, a NASFAM Business and Market Development Manager, and traditional chiefs. These provided technocratic perspectives on the questions of the study.

Additionally, the study conducted LHIs with 100 farming households. LHIs interviews are a qualitative method of data collection that elicits written narratives through questions and answers to describe or comment upon a person's own key stages in life (Bertaux, 1981; Olive, 2014). In this study, the LHls focused on childhood, youthhood, early adulthood, late adulthood and old age as the key stages of respondents' lives. The aim of the LHIs was to identify key turning points and the drivers of the turning points, be they positive or negative turning points. The households participating in the LHIs were selected to ensure representation of households in five different life trajectories, according to the Dorward et al. (2009) and Mushongah (2009) 
framework: stepping-out, stepping-up, hangingin, dropping-out, and stepping-in. Stepping-out implies diversifying away from agriculture; steppingup is when farmers intensify and expand agricultural production; hanging-in means farmers producing barely enough for subsistence; dropping-out entails farmers being pushed out of agriculture; and stepping in entails new people engaging in agriculture having mobilised resources from other livelihood strategies as well as those that never registered agricultural income at baseline (Matita et al., 2021). To reach theoretical qualitative saturation point, 20 heads of farming households were drawn from each of the five life trajectories. Interviews with qualitative researchers by Guest, Bunce and Johnson (2006) found that the theoretical saturation point is reached at the completion of at least the first 12 qualitative interviews. A later study by Guest, Namey and Chen (2020) also confirmed 12 qualitative interviews as being adequate for reaching saturation point.

Voice recorders were used in all interviews and FGDs in order to increase the accuracy of the data presented (Patton, 2002), and were later transcribed into English. Field notes were initially written for each KII, IDI, and FGD that was conducted. These were later supplemented by detailed transcribed data from each KII, IDI, and FGD. The data were analysed using thematic content analysis. Access to extension services, access to inputs, access to produce market, and challenges faced by FPOs and FPO members were the themes that guided the analysis of the data. First an initial long list of qualitative data codes was developed, before some codes that were found to be closely related and describing the same themes were merged. The development of the codes was a back and forth process that involved several code validation meetings by the research team. The codes were then used in coming up with quotations drawn from the transcribed qualitative data on different themes with the aid of a qualitative computer package ATLAS.ti. 


\section{RESULTS AND DISCUSSIONS}

\subsection{FPOs and access to extension}

\section{services}

Access to agricultural extension services is one of the important success factors in transforming smallholder agriculture (Masangano and Mthinda, 2012; Hagos and Geta, 2016). Farmers that access agricultural extension services are more likely to adopt modern and improved farming practices which in turn increases their yield. Farmers who enjoy high yields are likely to engage more with the market as the net of total yields minus home consumption requirements is positive and higher. Based on their study conducted in Malawi, Chikuni and Kilima (2019) concluded that channelling government's resources towards improving extension services and increasing farmers' productivity are ideal ways to promote the participation of smallholder farmers in agricultural markets.

The study found that farmers that belong to FPOs reported having more and frequent access to agricultural extension services. On the contrary, nonmembers of FPOs lamented how they fail to access extension services while their counterparts in FPOs more easily access diverse extension services. These findings corroborate findings by a study conducted in Guinea which found that 94.6 per cent of farmers with FPO membership had access to extension services, while only 31 per cent of farmers who did not belong to any FPO had access to extension services (Tolno et al., 2015). A similar study in Malawi by Mapila, Makwenda and Chitete (2010) lauded FPOs in Malaw for facilitating smallholder farmers' access to extension and marketing information.

In Malawi, agriculture extension and advisory services provided by the government operates on public goods principles. No willing farmer is excluded from accessing government extension services on any grounds. As long as government extension is provided in a particular area, all farmers are assured of accessing extension services if they want to. However, the challenge is that since the early 2000s, government extension services in Malawi have been overwhelmed with an exponential increase in the number of smallholder farmers, while there has been a slow growth in the number of government extension workers. This has seen one government extension worker being responsible for 3,500 farmers against the recommended 750 farmers (Government of Malawi, 2015 as cited in Cai and Davis, 2017; Masangano and Mthinda, 2012). As a consequence, government extension workers are unable to reach all willing farmers with agricultural extension and advisory services.

With the new liberalised and demand-driven agricultura extension policy that was operationalised in Malawi in early 2000s, NGOs and private sector companies like tobacco companies started providing frontline agricultural extension and advisory services to farmers. However, findings from FGDs, LHIs, and KIls in Malawi's central region districts of Mchinji and Ntchisi show that agricultural extension and advisory services provided by NGOs and private-sector companies are not freely accessible. Mostly, it is farmers that are members of FPOs like clubs, associations, and cooperatives that are accessing extension services provided by NGOs. Private companies are providing agricultural extension and advisory services either to their grower farmers or farmers who are contracted to them. Often, the private companies organise the farmers into groups and clubs. While it may look like a free service, upon selling their produce to the private companies they are affiliated to, private companied deduct a set service fee from farmers' sales income as payment for extension and advisory services which the farmers received from extension agents employed by the private companies.

Due to their rapidly increasing workload, government extension workers have also begun to prefer working with farmers that are organised in groups. This preference towards a group approach to extension delivery is being driven by the realisation that with the higher number of farmers that each extension worker is supposed to reach with extension and advisory services, a group approach is the most realistic way of ensuring that a larger proportion of farmers that need extension and advisory services are actually able to access the services. Therefore, regardless of which agent is offering agricultural extension and advisory services, smallholder farmers who are members of FPOs have higher access to such services than their non-member counterparts. This means that barriers that hinder other smallholder farmers from joining FPOs 
need to be addressed if all smallholder farmers are to have access to agricultural and advisory services. In a blog published by Futures Agriculture Consortium, Chimombo (2018) outlines these entry barriers, and they include membership registration fees, annual membership fees, and FPO deductions of sales income earned by FPOs members, which some smallholder farmers find to be unaffordable. This is worsened by FPOs' failure to secure profitable produce markets for their members, which is one of the key benefits that attract smallholder farmers to FPOs in the first place.

Farmers in clubs reported realising yields that were higher in quality and quantity because of the timely and continuous extension services. This, they attributed to good agricultural practices and skills acquired from extension services they access from their respective FPO.

Extension services which farmers' club members get are not limited to agronomic production practices but also cover issues of agricultural marketing.

'They [NASFAM' ${ }^{1}$ extension officers] only targeted cooperatives and their members and taught them how to determine investments, profits, losses, costs and other things. The rest of us who are not members of NASFAM farmer clubs [are] left out.' (FGD, mixed gender, nonclub, Nsitu, Mchinji).

'My grandmother did not actually receive professional extension advice except the time when she joined the pig farming club previously. Only that time, the extension officer came and shared with them how to take good care of the pigs and buyers that offer higher prices.' (LHI, late-adulthood, Mchinji)

\subsection{FPOs and access to credit and inputs}

Timely access to farm inputs is an important factor in enabling farmers to maximise farm yields. However, the regrettable reality is that in developing countries like Malawi access to farm inputs by smallholder farmers is often limited. This is why developing countries are now heavily investing in farm input subsidies (Government of Malawi, 2020). Income poverty, common among smallholder farmers, means that most important farm inputs like chemical fertilisers, pesticides, and hybrid seeds are often out of reach. Results from KIls, LHIs and FGDs reveal that farmers who are FPO members often have relatively greater and easier access to farm inputs relative to unorganised farmers who do not belong to a FPO. The study finds that most FPOs in the sampled districts of Mchinji and Kasungu can be described as standard rural organisations. By their definitions, standard rural organisations are established and supported by an external agency (van Heck, 1979). The agencies provide technical and/or financial support to the rural organisations they helped establish or they are working with (ibid). Most clubs in the two districts were found to be receiving financial and technical support from NGOs, government departments, and private companies. Private companies that work with and support farmers were mostly tobacco companies under contract farming arrangements. Most clubs were working with and getting support from NGOs like NASFAM, World Vision International, and Agricultural Commodity Exchange (ACE). The government, through various donor-funded projects (such as the Irrigation, Rural Livelihoods and Agricultural Development Programme) and departments (including Extension and Community Development) was also found to be providing support to FPOs in central Malawi.

The relationship between farmer clubs and external agencies were found to be beneficial to farmers, as far as access to farm inputs was concerned. With the exception of government agencies, the study found that NGOs and private tobacco companies improved farmer access to inputs in two ways. Firstly, NGOs provide farm inputs loans to farmers who are members of FPOs. Beneficiaries of such loans are required to pay back the loans in kind by paying back a portion of their harvests from the farming season in question. For example, members of FPOs under NASFAM were getting $25 \mathrm{~kg}$ of groundnuts seed and in turn repayed $50 \mathrm{~kg}$ of groundnuts to NASFAM upon harvesting their legume crop. Farmers find this arrangement to be very fair and reasonable, albeit subject to good rains during the farming season concerned.

'The good thing about NASFAM is that they give seed loans to all the members of NASFAM clubs regardless of their status. So access to modern and improved hybrid seeds is not a problem to us members of NASFAM clubs.' (FGD, mixed gender, club member, Chikwatula, Ntchisi)

'My wife joined a cooperative group which gives both fertiliser and seed loans which helped us start harvesting more maize and tobacco from the same piece of land.' (LHI, early adulthood, club member, Mchinji)

$1 \quad$ NASFAM is among the oldest civil society organisation in Malawi which organises smallholder farmers into clubs at a community level. 
'As a cooperative we have a marketing committee that goes out in search for markets with good prices so that we make profits. Sometimes, luckily, we are able to get inputs on loan with cheap interests, so the organisations that give us the loans buy our crops when they mature.' (FGD, men, club member, Mchinji)

The second way through which members of FPOs access inputs applies mostly to smallholder tobacco farmers under contract farming. Contract farmers are required to be in clubs by their contracting tobacco company. Through these clubs, smallholder tobacco farmers access farm input credit in the form of bags of chemical fertiliser and hybrid tobacco seeds. Unlike with the NGOs, the tobacco companies (like Alliance One, JTI, Malawi Leaf and Limbe Leaf) directly deduct the loan amount plus interest from farmers' tobacco sales. Farmers who benefit from this arrangement get net tobacco sales income, after the tobacco companies have already deducted the principal loan and interest. Furthermore, the study reveals that tobacco farmers belonging to tobacco farmer clubs also produce high tobacco yields of a higher quality because they apply sufficient amounts of chemical fertilisers, pesticides, and use high yielding hybrid seeds, all enabled by farm input loans and tailor-made extension services which tobacco companies provide to members of tobacco farmer clubs. While indeed tobacco contract farmers have high and easy access to farm input loans from tobacco companies, this study also finds that such loans are expensive for smallholder farmers as they are associated with high interest rates and other sundry charges. The finding on the expense of farm input loans under tobacco contract farming arrangement is discussed in more detail in subsequent paragraphs.

Members of FPOs have better access to farm input credit than non-members (Mapila, Kirsten and Meyer, 2012; Asante-Addo et al., 2016) because the FPO itself increases their members' creditworthiness while reducing the risk of defaulting loan repayment. Moreover, the FPOs act as collateral for the members, as the group is required to settle any credit defaulted by any of their members.

However, as already mentioned, the interest rates are very high on farm input loans provided to tobacco farmers who are members of tobacco farmer clubs under contract farming arrangement with tobacco companies. Farmers and key informants reported that the loan and interest deductions are so high that it is not uncommon for some farmers to have a negative net income, where sales income is lower than the cost of the principal loan and interest value. Non-member farmers, despite their inability to access sufficient farm inputs, perceive their counterparts under contract farming as being in inescapable input loan traps with tobacco companies.
Our findings on high interests on input loans suffered by tobacco farmers under contract arrangements run counter to study findings by Negri and Porto (2008). Using 2008 integrated household survey data for Malawi, Negri and Porto (2008) found that tobacco farmers in Malawi access cheaper credit with low interest rates. Our findings however validate with findings by Shaba et al. (2017) who found that 40 per cent of tobacco farmers on contract arrangement had seen their tobacco income earnings decrease over the past two years. Our findings, on high interest rates that farmers under contract arrangement face, provide one possible explanation as to why a significant number of tobacco farmers on contract arrangements experience a decrease in their tobacco incomes.

An African region study conducted by Key and Runsten (1999) concluded that while indeed farmers and tobacco companies enter into contracts, smallholder farmers' low literacy levels and failure understand contractual terms and conditions often results in smallholder farmers being taken advantage of by entering into contracts which they later discover were not in their interests due to high interest rates and other associated charges which smallholder farmers incur. The Government of Malawi (2016), through its contract farming strategy, makes it a requirement that farmers should use the services of CFTC to have their contracts vetted for fairness to prevent the exploitation of smallholder farmers. Unfortunately, the study did not find any evidence that farmers were aware of this requirement, or used CFTC services.

'Those on contract farming get extension services from extension agents employed by the tobacco buying companies and get also improved certified seeds and enough chemical fertilisers from the tobacco companies. Not surprising, farmers on contract produce high quality tobacco that fetch relatively higher prices at the auction floors compared to those that are not on contract. However, the high prices the farmers on tobacco contract farming get are offset by the higher loan deductions the farmers suffer at the hands of their respective tobacco companies.' (KII, extension worker, Mchinji)

Transactional cost economics views exploitative opportunism as inherently common in most transactional relationships between FPOs on the one hand and big companies that either supply inputs or buy farmers' produce on the other hand. One tool that is used to exploit farmers is information asymmetry. One of the parties seeking to unfairly benefit more than the other party hides some useful information from the other party. In doing so, the party without the information makes an uninformed decision and commitment 
based on incomplete information. Williamson (1985: 47), therefore, broadened the definition of opportunism to mean 'the incomplete or distorted disclosure of information, especially to calculated efforts to mislead, distort, disguise, obfuscate, or otherwise confuse'. It is no surprise, therefore, that the study found that tobacco farmers in clubs under contract farming arrangement were shocked every season to see the high loan interest deducted from their tobacco sales income. Clearly, farmers do not have access to the full terms and conditions of their contract with their tobacco contracting companies or are unable to read or understand it. Thus, tobacco farmers in clubs and on contract are falling victim to external opportunism.

The study also found that FPOs do not only ease and widen their members' ability to access farm inputs through external agencies like NGOs and private companies. On their own, without any external support and providence, farmers FPO members engage in village savings and loans activities. Through this process, members save and pool their resources together which are in turn made available for members to borrow on modest interest charges, far below the prevailing rates offered by micro-finance institutions and other financial services providers on the formal credit market. The savings enable members of FPOs to purchase sufficient amounts of farm inputs like fertilisers, pesticides and hybrid seed seeds, a feat which they could ordinarily not manage if they were not members of their respective FPOs.

'My wife is involved in the bank nkhonde (village savings and loans group) in the village. I provide the money that she deposits into the village and savings loans group from my wages. When time for buying farm inputs comes, she, like the rest of the members, withdraw the savings and use it to purchase adequate amounts of farm inputs. If it were not for the village savings and loans, I could have spent the money on less important things like beer and alcohol.' (LHI, men, early adulthood, Ntchisi)

\subsection{FPOs and access to structured and profitable markets}

One of the most touted benefits for smallholder farmers who join FPOs is enhanced access to profitable and structured markets (Mapila, Makwenda and Chitete, 2010; Ampaire, Machethe, and Birachi, 2013; Tolno et al., 2015). The study asked farmers and key informants to share their experiences on the agricultural produce market. We found that, overall, farmers who are members of FPOs are not accruing any advantages and benefits when selling their agricultural produce. Results show that just like non-FPO members, members are struggling and failing to secure structured and profitable markets for their agricultural produce. Only in few and isolated cases did farmers who are members of FPOs report having accessed structured and profitable markets as a consequence of their FPO membership.

Vendors remain the biggest buyers, and in fact they are in most cases the only buyers of farm produce available for both non-members and members of FPOs. Vendors are individual businesspeople who, acting as middlemen, engage in agricultural trading by buying farm produce from farmers. Their business model takes vendors and/or their buying agents deep into the villages where farmers are located. They buy the produce, sometimes even when not dry or mature enough, from farmers and re-sell the same to either final consumers or other retailers in big trading centres, towns, and cities. Alternatively, the vendors sell their produce to structured and profitable markets like big companies because, having social connections to decision-makers in those companies and having big quantities to supply at once, it is easier for them than for smallholder farmers to access such structured markets. The problem with vendors is that most of them have been accused of taking advantage of smallholder farmers' limited access to produce markets, and exploiting them by buying their produce at unreasonably low prices that are often below the farmers' breakeven points (Singh, 2010; Chikuni and Kilima 2019). Not only that, vendors have also been well documented in the literature as thriving on unfair business practices by, for example, manipulating weighing scales to their advantage at the expense of unsuspecting smallholder farmers (Chikuni and Kilima, 2019).

Respondents in this study, both farmers and Klls, collaborated previous studies that characterise vendors as exploitative due to their offering of low prices to farmers and also their engagement in other unfair trading practices. For example, farmers in both sampled districts for this study reported that a $50 \mathrm{~kg}$ bag of maize will weigh about $42 \mathrm{~kg}$ when weighed on a vendor-provided weighing scale, fleecing the farmer of payment for $8 \mathrm{~kg}$. Since typically most smallholder farmers do not have their own weighing scales, in nearly all produce buying transactions it is the vendor's weighing scale that is used. With few exceptions, farmers in the study, regardless of their club membership status, did not paint a positive picture of their experiences with vendors who buy their agricultural produce. They decried the perpetual season-to-season low prices that vendors offer for their farm produce. Asked why they still sell their produce to the vendors, both farmer club members and nonmembers pointed out that they do not have any choice 
because vendors are the only produce buyers readily available to them. By failing to secure alternative profitable and structured markets for their members, FPOs have therefore failed in meeting the promise of better and profitable markets which they make to their members. In doing so, members of FPOs in Malawi's two central regional districts are left with no option but the exploitative vendors as their only available market.

Rather than demonising vendors, however, they should instead be seen as saviours who buy smallholder farmers' produce when no one else (including the state produce buyer ADMARC and other quasi state and private companies) will, either because they are not willing to buy or have no resources to buy. It can be argued that without the vendors, smallholder farmers would have absolutely nowhere to sell their farm produce. This is more so in the prevailing liberalised market contexts in which state companies charged with the mandate of buying produce from farmers are run down and simply lack both the financial, administrative and technical capacity to discharge their core mandate. The appointment of board members and top management staff of such state companies, often based merely on political appeasements by rulers, has crippled the state produce buyer companies like ADMARC (Chinsinga, 2012; Chirwa and Chinsinga, 2015).

The study also found that attempts to aggregate produce for collective selling have not resulted in FPO members selling their produce at higher prices. While contradicting many study findings, such a finding is in sync with what Fischer and Qaim (2012) found in their Kenyan study on the effectiveness of farmer cooperatives in enhancing smallholder farmers access to profitable markets. Specifically, Fischer and Qaim (2012) found that membership in FPOs did not result in farmers accessing significantly higher prices for their farm produce. Our study finds that after warehousing the produce for months in anticipation of improved prices, sample FPO members ended up selling their produce at lower prices compared to prices offered by vendors earlier in the produce-buying season. Instead of prices picking up, the contrary happens when produce prices tumble as the produce-selling season progresses. When this happens, which according to farmers is what often happens, one of three actions are taken by FPOs. One possible action that is taken by the FPOs is allowing farmers to get back their respective produce deposits from the FPO's purpose-bult or make-shift warehouses which they end up selling to the same vendors who they were trying to avoid in the first place. In this case farmers end up selling their produce at even lower prices than prices which FPO non-member farmers sold their produce for at the beginning of the produce-buying season. In other cases, farmers reported that when they fail to secure profitable markets and produce prices start to deflate, the FPOs just sell the produce to the same vendors at the offered lower prices, in which case farmers face further deductions in terms of commission which is retained by their respective FPOs. Our study found that when stuck with unsold produce due to a failure to secure profitable markets, some FPOs choose to hold on to their produce by keeping it in their warehouses for more than one season. The downside of keeping the produce longer than one season is that the FPOs incur extra costs arising from produce rehandling and retreatment.

'The government does not monitor the markets of maize. Everyone just wakes up and sets their own prices for buying maize from smallholder farmers. Because of that the cooperatives did not sell their maize last year. The maize is still stuck in the warehouses after the cooperative, as is often the case in many seasons, failed to secure profitable markets. This is why some of us here are not joining the cooperative.' (FGD, mixed gender, non-club farmer, Nsitu, Mchinji)

'We harvest enough sometimes but we lack stable and proper markets so we just sell to vendors who offer very low buying prices now because we as smallholder farmers do not have any choice. Imagine in 2018, government said the minimum price for maize should be MK150/ $\mathrm{kg}$, but vendors were buying our maize at MK50/ $\mathrm{kg}$. We end up selling to the vendor and this is why smallholder farmers are not developing and when we say we should commercialise farming, we started hearing about this long time ago but how do you expect us to grow when there are no markets?' (FGD, men, club farmer, Cheka, Ntchisi)

Some farmers reported withdrawing their FPO membership after consistent failures by the club to secure good prices for their produce as they were promised when they were being persuaded to join. One such farmer expressed regret which was echoed by other FGD participants:

'I once went to another cooperative to drop my maize produce for marketing in early 2017 but until now late 2018 the crops have not yet been sold. I cannot go back to withdraw the crops because I will get less maize produce compared to the actual amount that I was supposed to receive due to the impact of post-harvest losses.' (FGD, men, nonclub members, Ntchisi) 
'When giving us the soybean seeds, NASFAM promises us that NASFAM will buy the soybean produce at a higher rate, but they just give a date to the people that they will come and buy but never show up.' (LHI, female, non-club member, early adulthood, Mchinji)

'We joined NASFAM club because they promised to give us hybrid soybean seeds on credit and buy our soybean produce at profit. NASFAM only gave us the promised $20 \mathrm{~kg}$ [per person] of hybrid soybean seeds. NASFAM did not keep its promise to buy our soybean produce. This was very frustrating. We ended up selling the soybean to vendors at ridiculously low prices.' (LHI, male, club member, late adulthood, Ntchisi)

In very isolated cases, farmers reported securing profitable markets through their FPOs. Such participants reported selling their produce to big companies at prices higher than the ones offered by vendors. Interestingly though, the study notes that most of the market success stories of farmers clubs were shared by key informants like extension workers, district senior agricultural officers and traditional leaders. This raised the question as to whether they were basing their views on actual experiences on the ground or on what they had read in books on market benefits of membership in FPOs. Out of the many FGDs, KIls, and LHIs, very few farmers reported accessing better markets for their produce because of their membership in FPOs.

'Farmers are organised into a club and do sell their soybeans to Export Trading Group and SunSeed Oil Company. This season (2017/2018), while vendors were buying soybeans at MK250/kg, SunSeed Oil Company and Export Trading Group were buying the same soybeans at MK280/kg from cooperatives in Malomo EPA [extension planning area].' (KII, agricultural extension worker, Nanthambwe EPA, Ntchisi)

'Those selling in groups are better off; vendors steal because they end up taking the same products and selling them in other or similar organisations. Being in a club is a good thing overall.' (KII, local chief, Mchinji)

'Those that sell collectively in bulk through cooperatives sell at better prices.' (KII, government official Ntchisi and KIll, government official Mchinji)

The story from tobacco farmers who are members of tobacco farmer clubs, under contract arrangements, is rather grey and poses as a dilemma as to whether it can be categorised as a market success story or not. We find that tobacco farmers who are in tobacco farmer clubs under contract farming arrangements with tobacco companies do sell their tobacco at higher prices than their counterparts who sell under the traditional auctioning system. Furthermore, results show that these tobacco farmers enjoy the lowest tobacco rejection rates than their counterparts under the traditional auction system. However, there is caveat to the good news that seems to cancel out the benefits enjoyed by the contracted tobacco farmers. Both farmers and key informants decried the huge deductions (in the form of loan repayments and interest) that they suffer at the hands of their contracting tobacco companies.

'Tobacco farmers on contract farming arrangements get better prices when selling their tobacco to their contracting tobacco companies compared to those farmers who are not on contract. However, the main challenge is that these farmers on contract are subjected to huge loan deductions that are made worse by high loan interests. Farmers on contract farming with tobacco companies are crying foul due to the exorbitant loans charges and deductions.' (KII, agricultural extension worker, Ntchisi)

'Not surprising, farmers on contract produce high quality tobacco that fetch relatively higher prices at the auction floors compared to those that are not on contract. However, the high prices the farmers on tobacco contract farming get are offset by the higher loan deductions the farmers suffer at the hands of their respective tobacco companies.' (KII, agricultural extension worker, Mchinji)

\subsection{Leadership and management issues in FPOs}

Effective leadership and management are important prerequisites in any efficient and effective farmer clubs. The study finds that poor leadership and poor management were singled out by former members of FPOs in central Malawi. FGDs with non-member farmers stated that most of them had previously been members of FPOs before they quit. Apart from the failure to access profitable markets, and high sales deductions by FPOs, the members mentioned poor leadership as one of the push factors that led them withdraw their club membership. The former club members singled out the 'founder syndrome' common in FPOs where leaders run the FPOs as their personal properties for their family's benefit. In addition, when it comes to distribution of club benefits and opportunities, club leaders were blamed for practicing 
favouritism and nepotism, with priority going to the leader's relatives and friends.

'Leadership issues play a role in farmers not joining club/cooperatives, because people who are in leadership positions in the clubs favour their own family members and relations in the cooperative. As a result, other farmers are demotivated from joining cooperatives.' (FGD, men, club members, Chiosya, Mchinji)

'Only the well to do join and benefit from the clubs.' (LHI, female, late-adulthood, Ntchisi)

In a working paper on the political economy of agricultural commercialisation, Chinsinga (2018) illustrated at great length how the agricultural sector in Malawi is captured by elites who use whatever platforms they can to advance their and their relations' interests. Elites often win leadership positions in FPOs. Even when ordinary members win leadership positions in FPOs, after attending training workshops aimed at building their leadership qualities often start seeing and conducting themselves as elites as well. As predicted by the theory of transactional costs economics, elites in FPOs turn out to be dysfunctional and toxic leaders as they engage in internal opportunism. They start appropriating all FPO benefits and opportunities for their inner circle of elites. The terms of reference for their positions are ignored and neglected. As agency theory argues, contracts like terms of reference for leadership positions in FPOs are often difficult and expensive to enforce.

Side-selling was found to be another limiting factor to the successful operations of FPOs in as far profitable collective marketing is concerned. Members of farmer clubs do not wholly adhere to the requirement of aggregating and warehousing their produce for collective marketing. Instead, the practice of members selling a proportion of their produce to vendors outside of the FPO system is common. This frustrates the ability of the FPO to control a big market share, which would enable them to become price setters rather than price takers. In addition, side selling makes FPO members compete with their own FPO. As far as principles governing collective marketing are concerned, this is a significant malpractice. However, farmers who engage in this malpractice justified their actions, blaming delayed payments from FPOs. Despite having immediate family needs like school fees payment and farm inputs procurement, farmers who sell their produce through FPOs have to wait a long time to receive income from their produce sales. Often, they end up failing to pay school fees for their children and fail to buy farm inputs like fertilisers and certified seeds due to payment delays. Failure to buy farm inputs has dire debilitating consequences for the next farming season in terms of yields and food security.

'Farmers who are in clubs complain that they sell their produce late which also results in them getting their payments late as well.' (KII, agricultural official Ntchisi)

'I sold groundnuts through Cheka farmer club which delayed to give us the money after they sold the groundnuts such that I failed to buy fertiliser.' (FGD, mixed gender, club member, Ntchisi)

It is common knowledge that smallholder farmers have immediate and urgent needs requiring money. This, therefore, calls for FPOs to be innovative in finding ways of enabling their members to access part payments once they deposit their produce in FPO warehouses for collective marketing purposes. Without this option, smallholder farmers will be forced by their immediate needs to continue engaging in side-selling and distress selling. Ochieng, Botha and Baulch (2020) reported how warehouse receipt systems are being used by ACE Malawi in enabling famers to access part payment for their produce deposit. As the farmers wait for ACE Malawi to secure markets for the produce, under the warehouse receipt system (WRS), farmers are given advance cash payment for their produce to enable them to meet their immediate needs. Through this process, the volume of produce being deposited to ACE warehouses increased significantly. There is therefore a need for FPOs to explore the feasibility of employing WRS while being cognisant of the fact that the system requires that the FPOs should have a good amount of idle money for making upfront payments to FPO members who deposit their produce to designated FPO warehouses.

Though reported as isolated cases by two clubs in Ntchisi, we found that there is a growing trend towards farmer clubs being duped of their aggregated farm produce by unscrupulous buyers. Such buyers negotiate with farmer clubs to buy their produce at very high prices which are very profitable to member farmers. These unscrupulous buyers purchase the produce on credit, promising to pay for the produce after they sell the produce to their multinational buyer at the end of the value chain. Lured by the prospects of higher profits, and working on trust, the produce is transported to the buyers' destination. With the produce in the buyers hands, they start to block communicating channels with the clubs, or change the goal posts on payment dates. In the end the farmer clubs are duped and they never get back their produce or money. This is a very big setback to the clubs and their members who are victims to such dishonesty 
and criminal behaviour by fraudsters masquerading as produce buyers.

'Cheka cooperative sold above 4,000 50kg bags of maize in early 2017 but still the cooperative has not received their payment up to now [late 2018]. The matters was taken to the court for ruling as the buyer is not cooperative. (FGD, men, non-club, Ntchisi)

'The cooperative drive in Kalira EPA is also under threat because farmers now have a negative attitude towards farmer cooperatives after several cooperatives in Ntchisi and one in Kalira in particular was duped two years ago by a produce buyer from Lilongwe who bought farmers' produce at better prices which she has never paid the farmers. The cooperative farmers lost over MK28 million in the process and may take time to trust cooperatives again.' (KII, agricultural extension worker, Ntchisi)

The duping of cooperatives of their hard-earned farm produce serves to give credence to the transaction cost economics theory which talks of how different actors in a business transaction engage in exploitative opportunistic behaviour at the expense of other parties. Williamson (1975: 255) famously defined 'opportunism' as 'self-interest seeking with guile'. He argued that 'Economic man is a much more subtle and devious creature than the usual self-interest seeking assumption reveals' (ibid.). Some cooperatives in central Malawi have been victims of traders who have fleeced them of their produce by taking them away and not honouring their promise to pay for it. While agency theory focuses on the principal-agent problem and always assumes that the agent, in this case FPO leaders and managers make decisions which serve only their interests at the expense of ordinary FPO members, this is not always the cause of all problems faced by FPOs. It is plausible to argue that duty bearers in FPOs entered into business deals with the traders with good and noble intensions, only to be betrayed by them. Since there is a high possibility that such theft by unscrupulous traders could occur, there is an urgent need to tighten due diligence procedures by developing airtight contract agreements with potential produce buyers. Such agreements should also detail the identity and background of the potential buyer. While agency theory warns that contracts are rarely enforced to the letter (Royer, 1999), such contracts can go a long way in tracking down unscrupulous traders who dupe farmers and hold them accountable.

The vices of side-selling, and duping farmers by taking their produce and not paying for the produce, is eroding the levels of trust in FPOs. There is also growing mistrusts among different stakeholders in FPOs. Cohen and Prusak (2001, as cited in Fu 2004) state that the success of any FPO hinges on cooperation and collective action but these two conditions cannot be realised if there is no trust. In fact, Gambetta (1988) posits that trust is the precondition to cooperation. However, trust requires people to be honest to each other and be able to keep their word and deliver on their commitments and promises. This is why trust, in business cycles, is seen as a tool that is used 'to impose some restraint on ourselves and thus restrict the extent to which others have to worry about our trustworthiness' (Gambetta, 1988: 221). The fact that FPOs have been failing to secure profitable markets for their members, and that FPO members have been engaging in side-selling, has eroded trust, thereby making FPO collective marketing very likely to fail. If cooperatives in the two study districts are to succeed, not only with their marketing objectives but also all other objectives, then efforts that build and strengthen trust within FPOs and between FPOs and other stakeholder like producer buyers are critical. 
The study has examined the effectiveness of FPOs in enhancing and promoting smallholder farmers' agricultural commercialisation. Specifically, based on qualitative data collected using LHIs, FGDs, and KIls, the study has interrogated the roles of FPOs in ensuring access to farm inputs, extension services and both output and input markets by smallholder farmers. Additionally, leadership and management issues constraining the effectiveness of FPOs have also been examined.

The study finds that the performance of FPOs in enhancing commercialisation of smallholder agriculture is a mixed bag of success and failure. On the success side, the study reveals that members of FPOs have more access to farm inputs than their non-member counterparts. Through farm inputs loan schemes and village savings and loans initiatives, members of FPOs have greater access to farm inputs. Through contract farming, tobacco farmers in tobacco farmers clubs access chemical fertilisers and high-yielding tobacco seeds, a reality which non-member smallholder tobacco farmers can only dream about. This increased access to farm inputs raises farm yields, which is one critical determinant of smallholder commercialisation, the importance of which cannot be overemphasised.

Another successful delivery by FPOs is increasing access to agricultural extension and advisory services for FPO members. Study results show that FPOs members, relative to non-members, have greater access to high quality and diverse agricultural extension and advisory services. As extension service providers are being constrained by the low number of extension staff, which is compounded by a rapid increase in the number of farmers, the use of FPOs as platforms for delivering agricultural extension and advisory services has become increasingly attractive. Farmers who are not members of any kind of FPOs, however, find themselves left out of most extension activities. As expected, membership in FPOs is therefore associated with high yields as the extension services motivates members to adopt yield-enhancing agricultural technologies. Farmers who enjoy high yields, ceteris paribus, engage more with output markets as they have a surplus to sell.

On the other hand, the study shows that FPOs have largely failed on their agricultural marketing role. Securing structured and profitable markets that offer high prices to members is perhaps one of the most important overarching benefits which farmers expect to gain from their membership in an FPO. As SNV (2016) points out, the extent of success of any FPO is related to the ability to control free riders through clear rules, enforceable contracts, social bonds with the farmers, competitiveness, and securing profitable markets that offer high prices for member farmers' produce. However, the study finds that FPOs in Malawi's central region districts of Mchinji and Ntchisi are failing to secure profitable markets that offer high prices for their members. Vendors, who are synonymous with offering low exploitative prices to farmers, remain the main buyers of produce from both FPOs and their members. This is one of the main reasons contributing to high member turnovers in FPOs in central Malawi as the incentive for farmers to maintain their membership is very low, a view also corroborated in previous studies (Matchaya, 2010; Matchaya and Peroton, 2013).

Apart from finding innovating ways of restricting and remodelling current FPOs in a such way that they become effective in securing profitable markets that offer high prices for their members, efforts also need to be exerted towards eliminating the challenges which are negatively affecting FPO performance in central Malawi as identified by the study. Specifically, problems of side-selling, elite-capture and theft by unscrupulous agricultural traders needs to be addressed. 


\section{IMPLICATIONS}

As a starting point, the study recommends the adoption of the WRS which makes cash immediately available to FPO members, as one way of dealing with the sideselling challenge. Clear and strongly enforceable rules and regulations, contracts and due diligence in buyer identification can go a long way in protecting FPO members from unscrupulous agricultural traders and elite capture.

The findings of the study indicate that instead of establishing more cooperatives, the government and NGOs should refocus their efforts in ensuring that already existing FPOs are efficient and effective in enabling their members secure sustainable profitable markets.

There is also a need for a comprehensive study that seeks to fully understand the characteristics, enablers, and constrainers of successful and effective FPOs that manage to facilitate the access of profitable markets for their members, over and above enhanced access to farm inputs and agricultural extension and advisory services. Through this process, the government and other stakeholders will be able to ensure that all FPOs are infused with identified success factors and enabling conditions.

This study did not interview nor conduct discussions with the buyers of farm produce and suppliers of farm inputs like vendors and contract companies. The study mitigated the limitation by gaining their perspectives from other secondary sources like the literature, yet future studies should include buyers of farm produce and suppliers of farm inputs to further solidify the balanced perspectives on the relationship and experiences that FPOs have with these very important actors on the agricultural market. In addition, while it is not easy to have access to contracts that farmers under contract farming sign with tobacco companies due to confidentiality clauses inherent in them, future studies should do their best to negotiate with tobacco companies to have a copy of the contract and assess whether there is any information asymmetry that disadvantages the farmers in terms of loan principal, interest rates and other charges. 
Alchian, A. and Demsetz, H. (1972) 'Production, Information costs, and economic organisation', American Economic Review, 62: 777-95

Ampaire, E., Machethe, C. and Birachi, E. (2013) 'The Role of Rural Producer Organizations in Enhancing Market Partcipation of Smallholder Farmers in Uganda: Enabling and Disabling Factors', African Journal of Agricultural Research 8(11): 963-970.

Arias, P., Hallam, D., Krivonos, E. and Morrison, J. (2013) Smallholder integration in food markets. Rome: Food and Agriculture Organization of the United Nations.

Asante-Addo, C., Mockshell, J., Siddig, K. and Zeller, M. (2016) 'Agricultural credit provision: What really determines farmers' participation and credit rationing', paper presented at 5th International Conference of the African Association of Agricultural Economists, Addis Ababa, September 23-26.

Barrett, C.B. (2008) 'Smallholder market participation: Concept and evidence from eastern and southern Africa', Food Policy 33(4): 299-317.

Bellemare, M.F., and Barrett, C.B. (2006) 'An ordered tobit model of market participation: Evidence from Kenya and Ethiopia', American Journal of Agricultural Economics 88(2): 324-337.

Bernard, T. and Spielman, D. (2009) 'Reaching the Rural poor through Rural Producer Organizations. A study of Agricultural Marketing Cooperatives in Ethiopia', Food Policy 34(1): 60-69. http://dx.doi.org/10.1016/j. foodpol.2008.08.001.

Bernard, T., Seyoum, T.A. and Gabre-Madhin, E. (2008) 'Impact of Cooperatives on Smallholders' Commercialization behavior: Evidence from Ethiopia', Agricultural Economics 39(2): 147-161. http://dx.doi. org/10.1111/j.1574-0862.2008.00324.x.

Bertaux, D. (ed.) (1981) Biography and society: the life history approach in the social sciences. Beverly Hills: Sage Publications.

Bonus, H. (1986) 'The cooperative association as a business enterprise: a study in the economics of transactions', Journal of Institutional and Theoretical Economics 142: 310-399.

Borda-Rodriguez, A. and Vicari, S. (2014) 'Rural co-operative resilience: The case of Malawi', Journal of Cooperative Organisation and Management 2(1): 43-52.

Borgen, S.O. (2004) 'Rethinking incentive problems in coopera-tive organizations', Journal of Socio-Economics 33(4): 383-393.

Cai, T. and Davis, K. (2017) Malawi: Desk Study of Extension and Advisory Services. Lilongwe: Global Forum for Rural Advisory Services.

Chikuni, T. and Kilima, F. T. (2019) 'Smallholder farmers' market participation and mobile phone-based market information services in Lilongwe, Malawi', The Electronic Journal of Information Systems in Developing Countries 85(6): p.e12097. https://doi.org/10.1002/isd2.12097

Chimombo, M. (2018) 'Failed Promises: The Decline of Cooperative Membership in Malawi', Future Agricultures Blog [online], 27 September. Available at: https://www.future-agricultures.org/blog/failed-promises-the-declineof-cooperative-membership-in-malawi/ (Accessed: 28 January 2022). 
Chinsinga, B. (2012) The Political Economy of Agricultural Policy Processes in Malawi: A Case Study of the Fertilizer Subsidy Programme. FAC Working Paper 39. Brighton: Future Agricultures Consortium. Available at: https://opendocs.ids.ac.uk/opendocs/handle/20.500.12413/2249 (Accessed: 14 July 2021).

Chinsinga, B. (2018) The Political Economy of Agricultural Commercialisation in Malawi. APRA Working Paper 17. Brighton: Future Agricultures Consortium. Available at https://opendocs.ids.ac.uk/opendocs/ handle/20.500.12413/14028 (Accessed: 27 March 2019).

Chirwa, E.W. (2011) 'Competition Issues in the Tobacco Industry of Malawi', Paper prepared for UNCTAD Secretariat, United Nations, New York and Geneva.

Chirwa, E. and Chinsinga, B. (2015) 'The Political Economy of Food Price Policy in Malawi', in P. Pinstrup-Andersen (ed.), Food Price Policy in an Era of Market Instability: A Political Economy Analysis. Oxford: Oxford University Press.

Cleland, J.A. (2017) 'The qualitative orientation in medical education research', Korean Journal of Medical Education 29(2): 61-71.

Cohen, D. and Prusak, L. (2001) In Good Company: How Social Capital Makes Organizations Work. Harvard: Harvard Business Press.

Collier, P. and Dercon, S. (2014) 'African Agriculture in 50 Years: Smallholders in a Rapidly Changing World?', World Development 63: 92-101.

Cook, M.L. (1995), 'The future of U.S. agricultural cooperatives: a neo-institutional approach', American Journal of Agricultural Economics 77:1153-1159.

Cook, M.L., and lliopoulos, C. (2000) 'Ill-defined property rights in collective action:the case of US agricultural cooperatives', in C. Menard, (ed.) Institutions, Contracts, and Organizations: Perspectives from New Institutional Economics. London: Edward Elgar Publishing.

DeVoe, D. (2014) Cultivating change. Lilongwe: produced by CRS on behalf of the WALA and IMPACT program consortiums.

Dollar, D. and Kraay, A. (2004) 'Trade, Growth, and Poverty', Economic Journal, 114: $22-49$.

Dorward, A., Anderson, S., Nava, B.Y., Sanchez, V.E., Rushton, J., Pattison, J. and Paz, R. (2009) 'Hanging in, stepping up and stepping out: Livelihood aspirations and strategies of the poor', Development in Practice 19(2): 240-247.

Eliasi, B., Aubin, S. and Sunga, I. (2009) 'Enhancing smallholder farmers policy engagement through greater involvement of farmer organizations in policy processes.' Paper presented at the IDASA Economic governance programme conference on 'Governance and small-scale agriculture in Southern Africa'. Southern African Confederation of Agricultural Unions.

Fafchamps, M. (1992) 'Cash crop production, food price volatility, and rural market integration in the third world', American Journal of Agricultural Economics 74(I): 90-99.

Fama, E. (1980) 'Agency problems and the theory of the firm', Journal of Political Economy, 88: 288-307.

Fama, E. and Jensen, M. (1983) 'Separation of ownership and control', Journal of Law and Economics 26: 301325.

FAO (2007) Sustainable Agriculture and Rural Development (SARD) and farmer organizations. SARD Policy brief No. 12. Rome: Food and Agriculture Organization of the United Nations.

Fischer, E. and Qaim, M. (2012) 'Linking smallholders to markets: Determinants and impacts of farmer collective action in Kenya', World Development Journal 40(6): 1255-1268. http://dx.doi.org/10.1016/j.worlddev.2011.11.018.

Fischer, E. and Quaim, M. (2013) 'Smallholder farmers and collective action: What determines the intensity of participation?' Journal of Agricultural Economics 65(3): 683-702. http://dx.doi.org/10.1111/1477-9552.12060.

Frey, H. and Fontana, A. (1991) 'The group interview in social research', Social Science Journal 28: 175-187. 
Fu, Q. (2004) Trust, Social Capital, and Organizational Effectiveness. MA Dissertation, Virginia Polytechnic Institute and State University, Blacksburg, VA.

Gabre-Madhin, E.Z. (2009) A Market for all Farmers: Market Institutions and Smallholder Participation. CEGA Working Paper Series No. AfD-0903. Center of Evaluation for Global Action. Berkeley: University of California.

Gambetta, D. (1988) Trust: Making and Breaking Cooperative Relations. Oxford: Blackwell.

Gebremedhin, B. and Jaleta, M. (2010) 'Commercialization of smallholders: is market participation enough?', Paper presented at the Joint 3rd African Association of Agricultural Economists (AAAE) and 48th agricultural economists Association of South Africa (AEASA) conference, Cape Town, South Africa, September 19-23.

Government of Malawi (1997) Cooperative Development Policy. Available at: https://cepa.rmportal.net/Library/ government-publications/Cooperative\%20Development\%20Policy\%201997.pdf (Accessed: 5 January 2022).

Government of Malawi (1998) Cooperative Societies Act. Available at: http://extwprlegs1.fao.org/docs/pdf/ mlw117870.pdf (Accessed: 5 January 2022).

Government of Malawi (2016) Contract Farming Strategy. Available at: https://www.canr.msu.edu/fsp/countries/ malawi/Contract\%20Farming\%20Strategy\%20final\%20\%20version.pdf (Accessed: 5 January 2022).

Government of Malawi (2020) Ministerial Statement on the Affordable Inputs Programme to the National Assembly by the Minister of Agriculture. Ministry of Agriculture, Lilongwe, Malawi.

Government of Malawi (2021) Malawi Vision 2063: An Inclusively Wealthy and Self-reliant Nation. Available at: https://malawi.un.org/sites/default/files/2021-01/MW2063-\%20Malawi\%20Vision\%202063\%20Document.pdf (Accessed:27 November 2021).

Guest, G., Bunce, A. and Johnson, L. (2006) 'How many interviews are enough? An experiment with data saturation and variability', Field Methods 18: 59-82. https://doi.org/10.1177/1525822X05279903.

Guest, G., Namey, E. and Chen, M. (2020) 'A simple method to assess and report thematic saturation in qualitative research', PLoS ONE 15(5): 0232076. https://doi.org/10.1371/journal.pone.0232076.

Hagos, A. and Geta, E. (2016) 'Review on small holders agriculture commercialization in Ethiopia: What are the driving factors to focused on?', Journal of Development and Agricultural Economics 8(4): 65-76.

Hansmann, H. (1996) The Ownership of Enterprise. Cambridge: The Belknap Press of Harvard University Press. Iliopoulos, C. and Hendrikse, G.W.J. (2009) 'Influence costs in agribusiness co-operatives: evidence from case studies', International Studies of Management and Organization 39(4), 60-80.

Iliopoulos, C. and Valentinov, V. (2012) 'Opportunism in Agricultural Cooperatives in Greece', Outlook on Agriculture 41(1): 15-19. http://dx.doi.org/10.5367/oa.2012.0071.

ILO (2017) Use of Statistics on Cooperatives in National Policy Making. Geneva: International Labour Organization.

IMF (2007) Malawi: Poverty reduction strategy paper-Growth and Development Strategy. Country report number 07/55. Washington DC: International Monetary Fund. Available at: http://www.imf.org/external/pubs/ft/scr/2007/ cr0755.pdf (Accessed: 17 August 2019).

Kachule, R. (2004) Rural Producer Organizations and Policy Formulation in Malawi. Agricultural Policy Research Unit Working Paper No. 127. Lilongwe: Bunda College of Agriculture.

Kadzola, S. (2009) 'Cooperatives in Malawi: Past, Present and Future'. Paper presented at the The First International Cooperatives Conference in Kwa Zulu Natal Province, 23-26 February.

Keller, W. and Shiue, C.H. (2007) 'Market integration and economic development: a long-run comparison', Review of Development Economics, 11: 107-123.

Key, N. and Runsten, D. (1999) 'Contract farming, smallholders, and rural development in Latin America: The organization of agro-processing firms and the scale of out-grower production', World Development 27(2): 381401. 
Kumwenda, I. and Madola, M. (2005) The Status of Contract Farming in Malawi. Lilongwe: Food, Agriculture and Natural Resources Policy Analysis Network. Available at: https://citeseerx.ist.psu.edu/viewdoc/ download?doi=10.1.1.531.8082\&rep=rep1\&type=pdf (Accessed: 12 January 2022).

Kusumawati, R. and Visser, L. (2016) 'Capturing the elite in marine conservation in Northeast Kalimantan', Human Ecology 44: 301-310.

Mango, N., Makate, C., Lundy, M., Siziba, S., Nyikahadzoi, K. and Fatunbi, A.O. (2017) 'Collective market participation for improved income among smallholder farming households: a case of Balaka Innovation Platform in Malawi', African Crop Science Journal 25(s1): 97-108. http://dx.doi.org/10.4314/acsj.v25i1.8S.

Mapila, M., Kirsten, J. and Meyer, F.H. (2012) 'Macro-Micro Linkages and Rural Livelihood Improvements in Africa', Journal of Agricultural Extension and Rural Development 13(6): 123-130.

Mapila, M., Makwenda, B. and Chitete, D. (2010) 'Elitism in Farmer Organizations in Post-Colonial Malawi', Journal of Agricultural Extension and Rural Development 2(8): 144-153.

Masangano, C. and Mthinda, C. (2012) 'Pluralistic Extension System in Malawi'. IFPRI Discussion Paper 01171. Washington DC: International Food Policy Research Institute.

Matchaya, G.C. (2010) 'Cooperative patronage: The National Smallholder Farmers' Association of Malawi in Kasungu District', Development Southern Africa 27(3): 397-412. https://doi.org/10.1080/0376835X.2010.498950.

Matchaya, G.C. and Perotin V. (2013) 'The impact of cooperative patronage: The case of National Small Holder Farmers' Association (NASFAM) of Malawi in Kasungu District', Agrekon 52(2): 75-103. https://doi.org/10.1080/0 3031853.2013.798066.

Matita, M., Chirwa, E., Kaiyatsa, S., Mazalale, J., Chimombo, M., Mgalamadzi, L. and Chinsinga, B. (2021) Determinants of Smallholder Farmers' Livelihood Trajectories: Evidence from Rural Malawi. APRA Working Paper 50. Brighton: Future Agricultures Consortium. Available at: https://opendocs.ids.ac.uk/opendocs/ handle/20.500.12413/16479 (Accessed: 4 August 2021).

Mushongah, J. (2009) Rethinking Vulnerability: Livelihood Change in Southern Zimbabwe, 1986-2006. Brighton: University of Sussex.

Nwafor, C., Nwafor, I.C. and Ogundeji, A. (2020) A Review of Agricultural Extension and Advisory Services in subSaharan African Countries: Progress with Private Sector Involvement. Available at: https://www.researchgate. net/publication/343537971_A_Review_of_Agricultural_Extension_and_Advisory_Services_in_sub-_Saharan_ African_Countries_Progress_with_Private_Sector_Involvement (Accessed: 7 September 2020).

Negri, M. and Porto, G. (2008) Burley Tobacco Clubs in Malawi: Nonmarket Institutions for Exports. Working Paper No. 6210. Washington DC: World Bank.

Ochieng, D.O., Botha, R. and Baulch, B. (2020) Market Information and access to Structured Markets by Small farmers and Traders: Evidence from a Randomized Experiment in Central Malawi. MaSSP Working Paper No 33. Lilongwe: International Food Policy Research Institute.

Olive, J.L. (2014) 'Reflecting on the Tensions Between Emic and Etic Perspectives in Life History Research: Lessons Learned', Forum Qualitative Sozialforschung/Forum: Qualitative Social Research 15(26). ISSN 14385627.

Ortmann, G.F. and King, R.P. (2007) 'Agricultural Cooperatives I: History, Theory and Problems', Agrekon: Agricultural Economics Research, Policy and Practice in Southern Africa 46(1): 18-46. http://dx.doi.org/10.1080/ 03031853.2007.9523760.

Patton, M. (2002) Qualitative Research and Evaluation Methods. Thousand Oaks: Sage Publications.

Pingali, P. (1997) 'From subsistence to commercial production System: The transformation of Asian agriculture', American Journal of Agricultural Economics 79(2): 628-634.

Pingali, L.P. and Rosegrant, M.W. (1995) 'Agricultural commercialization and diversification: Process and polices', Food Policy 20(3): 171-185. 
Rondot, P. and Collion, M. (2001) Agricultural Producer Organizations: Their Contribution to Rural Capacity Building and Poverty Reduction. Washington, DC: World Bank

Royer, J.S. (1999) 'Cooperative organizational strategies: A neo-institutional digest', Journal of Cooperatives 14: 44-67.

Silverman, D. (2006) Interpreting Qualitative Data: Methods for Analysing Talk, Text and Interaction (Third edition). London: Sage.

Silverman, D. (ed.) (2016) Qualitative research (Forth Edition). Los Angeles: Sage.

Singh, S. (2010) 'Micro-Finance in Bihar: Status and Challenges', Paper prepared for International conference on Development of Bihar: Status and Challenges, organised by Department of Economics, Patna University and IHD, New Delhi at Patna, March 4-5.

SNV (2016) Producer Organizations: Going into Markets with Formal Markets. USA: Netherlands Development Organization.

Shaba, A.K., Edriss, A.K., Mangisoni, J.H. and Phiri, M.A.R. (2017) Tobacco Contractual Arrangements in Malawi and their Impact on Smallholder Farmers - Evidence from Malawi. Working Paper No. 18. Lilongwe: International Food Policy Research Institute.

Shiferaw, B., Hellin, J. and Muricho, G. (2011) 'Improving market access and agricultural productivity growth in Africa: what role for producer organizations and collective action institutions?', Food Security 3(4): 475-489. http:// dx.doi.org/10.1007/s12571-011-0153-0

Staatz, J.M. (1987) 'Farmers' incentives to take collective action via cooperatives: a transaction cost approach', in J. Royer (ed.) Cooperative Theory: New Approaches, Service Report 18, Agricultural Cooperative Service. Washington, DC: United States Department for Agriculture.

Sykuta, M.E. and Chaddad, F.R. (1999) 'Putting theories of the firm in their place: A supplemental digest of the new institutional economics', Journal of Cooperatives 14: 68-76.

Timmer, C.P. (1997) 'Farmers and markets: The political economy of new paradigms', American Journal of Agricultural Economics 79(2): 621-627.

Tittonell, P. and Giller, K.E. (2013) 'When yield gaps are poverty traps: The paradigm of ecological intensification in African smallholder agriculture', Field Crops Research 143: 76-90. http://dx.doi.org/10.1016/j.fcr.2012.10.007.

Tolno, E., Kobayashi, H., Ichiza, M., Esham, M. and Balde, B. (2015) 'Economic Analysis of the Role Farmer Organizations in Enhancing Smallholder Potato Farmers' Income in Middle Guinea', Journal of Agricultural Sciences 7(3): 123-137. http://dx.doi.org/10.5539/jas.V7n3p123

Van Heck, B. (1979) Participation of the Poor in Rural Organizations: A Consolidated Report on Studies in Selected Countries of Asia, Near East and Africa. Rome: Food and Agriculture Organization of the United Nations.

Vicari, S. and Borda-Rodriguez, A. (2014) Building Resilience in the Malawian Co-operative Movement. Manchester: The Cooperative College.

Vitaliano, P. (1983) 'Cooperative enterprise: an alternative conceptual basis for analyzing a complex institution', American Journal of Agricultural Economics 65: 1078-1083.

Von Braun, J. (1995) 'Agricultural commercialization: impacts on income and nutrition and implications for policy', Food Policy 20(3): 187-202.

Von Braun, J., Kennedy, E. and Bouis, H. (1990) 'Commercialization of smallholder agriculture: Policy requirements for the malnourished poor', Food Policy 15(1): 82-85. doi:10.1016/0306-9192(90)90027-w.

Williamson, O.E. (1975) Markets and hierarchies, analysis and antitrust implications: A study in the economics of internal organization. New York: Free Press 
Williamson, O.E. (1985) The economic institutions of capitalism: firms, markets, relational contracting. New York: Free Press.

Williamson, O. (1996) The Mechanisms of Governance. Oxford: Oxford University Press.

Williamson, O.E. (2004) 'Transaction cost economics and agriculture: an excursion', in: G. van Huylenbroeck, W. Verbeke and L. Lauwers (eds.), Role of Institutions in Rural Policies and Agricultural Markets. Amsterdam: Elsevier. Yin, R.K. (2003) Case study research: design and methods. Thousand Oaks: Sage Publications. 
Chimombo, M., Matita, M., Mgalamadzi, L., Chinsinga, B., Chirwa, E.W., Kaiyatsa, S. and Mazalale, J. (2022) Interrogating the Effectiveness of Farmer Producer Organisations in Enhancing Smallholder Commercialisation - Frontline Experiences from Central Malawi. APRA Working Paper 82. Brighton: Future Agricultures Consortium.

(c) APRA 2022

ISBN: 978-1-78118-913-9

DOI: 10.19088/APRA.2022.004

\section{(cc) BY-NC-ND}

This is an Open Access report distributed under the terms of the Attribution-Non Commercial-No Derivs 4.0 Unported (CC BY-NC-ND 4.0) Attribution - You must give appropriate credit, provide a link to the license, and indicate if changes were made. You may do so in any reasonable manner, but not in any way that suggests the licensor endorses you or your use. NonCommercial — You may not use the material for commercial purposes. NoDerivatives - If you remix, transform, or build upon the material, you may not distribute the modified material. You are free to: Share - copy and redistribute the material in any medium or format.

https://creativecommons.org/licenses/by-nc-nd/4.0/legalcode

If you use the work, we ask that you reference the APRA website (www.future-agricultures.org/apra/) and send a copy of the work or a link to its use online to the following address for our archive: APRA, Future Agricultures Consortium, University of Sussex, Brighton BN1 9RE, UK (apra@ids.ac.uk)

All APRA Working Papers go through a review process before publication.

\section{Cccreative}

DO YOU HAVE COMMENTS ON THIS PAPER?

We would welcome your feedback on this working paper!

To provide brief comments, please follow this link to our short APRA Working Paper Feedback form: https://goo.gl/forms/1iVnXhhrIGesfR9

Agricultural Policy Research in Africa (APRA) is a programme of the Future Agricultures Consortium (FAC) which is

generating new evidence and policy-relevant insights on more inclusive pathways to agricultural commercialisation in sub-Saharan Africa. APRA is funded with UK aid from the UK Foreign, Commonwealth \&

Development Office (FCDO) and will run from 2016-2022.

The APRA Directorate is based at the Institute of Development Studies (IDS), UK (www.ids.ac.uk), with regional hubs at the Centre for African

Bio-Entrepreneurship (CABE), Kenya, the Institute for Poverty, Land and Agrarian Studies (PLAAS), South Africa, and the University of Ghana, Legon. It

builds on more than a decade of research and policy engagement work by the Future Agricultures Consortium (www.future-agricultures.org) and involves more than 100 researchers and communications professionals in Africa, UK, Sweden and USA. 